\title{
The Impact of Mass Layoffs on the Educational Investments of Working College Students
}

\author{
Ben Ost ${ }^{\mathrm{a}}$, Weixiang Pan ${ }^{\mathrm{a}}$ and Doug Webber ${ }^{\mathrm{b}}$ \\ ${ }^{a}$ Department of Economics, University of Illinois at Chicago, 601 South Morgan UH718 \\ M/C144 Chicago, IL 60607, United States \\ ${ }^{\mathrm{b}}$ Corresponding Author. Department of Economics, Temple University, 1301 Cecil B. \\ Moore, Ritter Annex Office 883 Philadelphia, Pennsylvania 19122. \\ Email:douglas.webber@temple.edu phone: (215-204-5025)
}

\begin{abstract}
Analyzing how working students weather personal economic shocks is increasingly important as the fraction of college students working substantial hours has increased dramatically over the past few decades. Using administrative data on Ohio college students linked to matched firm-worker data on earnings, we examine how layoff affects the educational outcomes of working college students. Theoretically, layoff decreases the opportunity cost of college enrollment, but it could also make financing one's education more difficult, so the net effect is ambiguous. We find that layoff leads to a considerable reduction in the probability of employment while in school, but it has little impact on enrollment decisions at the extensive margin. On the intensive margin, we find that layoff leads to an increase in enrolled credits, consistent with the fact that the opportunity cost of college has decreased.
\end{abstract}

We particularly thank Lisa Neilson and the entire Ohio Education Research Data Center for making available the data used in this study. Legal disclaimer: This workforce solution was funded by a grant awarded to the U.S. Department of Labor's Employment and Training Administration. The solution was created by the Center for Human Resource Research on behalf of the Ohio Department of Job and Family Services and does not necessarily reflect the official position of the U.S. Department of Labor. The Department of Labor makes no guarantees, warranties, or assurances of any kind, express or implied, with respect to such information, including any information on linked sites and including, but not limited to, accuracy of the information or its completeness, timeliness, usefulness, adequacy, continued availability, or ownership. This solution is copyrighted by the institution that created it. Internal use, by an organization and/or personal use by an individual for non-commercial purposes, is permissible. All other uses require the prior authorization of the copyright owner. 


\section{Introduction}

Over the past 40 years, there has been an unprecedented rise in the fraction of college students who simultaneously enroll full time in school and work in the labor force. In 2011, 72 percent of college students worked and 20 percent of college students were employed full time (Davis 2012). Given the relatively high labor force participation of today's college students, it is increasingly relevant to understand not only how college attendance impacts future labor market success, but also how contemporaneous labor market events impact college attendance. Our study explores such a question by considering how students’ educational investments change as a result of layoff.

While the consequences of job loss have been studied extensively (Jacobson Lalonde and Sullivan, 1993; Charles and Stephens Jr., 2004; Brand et al., 2008; Sullivan and Von Wachter, 2009; Couch and Placzek, 2010; Hallock et al., 2012), being laid off as a college student presents a unique set of challenges. First, working students may rely on their labor market earnings to pay college tuition. To the extent that working students face credit constraints, those who are laid off might be forced to withdraw, take time off, or reduce their course load. Second, though financial considerations could necessitate reductions in college attendance, laid-off workers also have additional time to invest in college and thus might be more likely to persist in college, increase their course load, or improve their grades. Thus, the theoretical impact on educational investment is ambiguous.

Our study provides the first evidence of the impact of job loss on the educational outcomes of working students. We use administrative matched employer-employee data for nearly every worker in the state of Ohio linked to administrative data on higher 
educational enrollment at all Ohio public universities to identify students working at firms that experience mass layoffs. We then explore how these students respond to the layoff in terms of their enrollment decisions, credits attempted, GPA, and borrowing behavior. These data are uniquely well suited to answering this question because they provide detailed information on both labor market and educational outcomes for a large sample of individuals.

The primary empirical obstacle to estimating the impact of losing one's job on educational investment is the possibility that individuals who lose their jobs differ from those who remain continuously employed at the same establishment. In other contexts, workers who experience job loss have been shown to be quite different than their counterparts who remained employed, with these differences persisting even when focusing on individuals who are displaced as part of a mass layoff event (Hilger, 2016). We address this issue by exploiting data on the exact timing of the layoff event for each individual. Essentially, we focus on students who are working at a firm that will have a mass layoff event in the near future, but at different points in their college careers. Our treatment group is the set of students whose firm will have a mass layoff event during their first year enrolled in school. Our control group is the set of students whose firstyear firm will have a mass layoff event during their third year. ${ }^{1}$ We then measure all outcomes during the fall semester of the second year so that the treatment group's layoff could impact the outcomes, but the control group has not yet experienced a layoff. The

\footnotetext{
${ }^{1}$ Importantly, we define the treatment and control group entirely based on the firm that a student is working at during their first year. In other words, the control group consists of students whose first-year firm will have a mass layoff in two years. To avoid sample selection, students are considered as part of the control group even if they are no longer at their first-year firm when the mass layoff event occurs.
} 
treatment and control group both work at the type of firm that experiences layoff events and only differ in terms of the timing at which that event occurs. We show that these two groups have quite similar observable characteristics which provides reassurance that the control group likely yields a valid counterfactual for the treatment group.

Given that the treatment and control groups are similar in terms of their characteristics, the main threat to our identification strategy is the possibility that the control group could anticipate their future layoff and is thus partially treated. This concern is particularly pertinent since it is well known that laid-off workers begin to experience earnings declines several quarters prior to the layoff event, a feature often referred to as an Ashenfelter dip (Ashenfelter, 1978). To the extent that this anticipation effect occurs, our estimates will be downwardly biased since the control group might be thought of as partially treated. We provide several pieces of evidence suggesting that this is not a major concern in our context. Most importantly, there is a large employment gap in the second year between our control and treatment group. Furthermore, we show that our estimates are broadly robust to several alternative identification strategies that could not be affected by anticipation effects.

Our study is complementary to two broad literatures that explore how the labor market impacts educational investment. First, several papers have explored how aggregate college enrollment changes in response to recessions (Berger and Kostal, 2002; Betts and McFarland, 1995; Card and Lemieux, 2000). Second, a large literature seeks to understand how working during college hinders or helps college performance (Ehrenberg and Shreman, 1987; Hotz et al, 2002; Stinebrickner and Stinebrickner, 2003; Hakkinen, 2006). 
The literature studying how aggregate enrollment responds to labor market downturns is motivated by the notion that recessions lower the opportunity cost of college by reducing current labor market opportunities (Betts and McFarland, 1995). Past work has used variation in local unemployment rates to assess whether college enrollment rises or falls in response to changing labor market conditions. Our study complements this aggregated analysis by using micro-level variation in individual employment opportunities. We view our study as complementary to this literature as opposed to directly comparable because there are several reasons that individual layoffs may lead to a different effect compared to aggregate changes in employment opportunities. First, in addition to reducing current employment, being laid off likely reduces individual wealth and this wealth reduction could directly impact enrollment if credits constraints bind. Second, individual job loss will not impact supply side factors whereas a generally weak labor force could alter university funding directly. Finally, unlike studies of aggregate enrollment cyclicality that emphasize initial enrollment decisions, our study is focused on whether individuals who initially were working while in college decide to drop out.

The literature that studies the impact of working during college on academic performance is motivated by the idea that students who work many hours during college may develop useful skills through that work, but may also be unable to devote sufficient time to their studies. Though few studies in this literature can completely overcome the problem that employment decisions are endogenous, most studies find that large amounts of work is detrimental to educational outcomes (Ehrenberg and Sherman, 1987; Hakkinen, 2006). This conclusion is broadly confirmed by Stinebrickner and 
Stinebrickner (2003) who use quasi-experimental variation in the amount of time spent working based on the assignment of work study jobs.

Though conceptually related, our study identifies a somewhat different parameter than the literature estimating the impact of working during college. Past work typically compares academic outcomes for students who choose to work to otherwise similar students who choose not to work. Our study, however, compares students who choose to work to otherwise similar students who are no longer allowed to work at their former job. This difference suggests that our study identifies the impact of working for a somewhat different population compared to the prior literature. Furthermore, since laid-off students are likely to be searching for employment, our estimates include this job search effect.

Our study is most closely related Frenette, Upward and Wright (2011) that considers the impact of mass-layoff on the post-secondary enrollment of workers. They find that workers affected by mass-layoff events are slightly more likely to subsequently enroll in college compared to workers not affected by mass-layoff events. Our study differs from Frenette, Upward and Wright (2011) in several ways. First, our study is focused on whether working college students persist whereas their study is focused on initial enrollment decisions of the general work force. Second, their work only considers the enrollment decisions at the extensive margin whereas our administrative higher education data allows us to study credits attempted, GPA, and borrowing behavior. Finally, the identification strategy used in Frenette, Upward and Wright (2011) relies on the comparability of individuals working at firms with mass layoffs and individuals working at firms without mass layoffs. 
We find that losing one's job substantially reduces the probability of employment in the following term. On the intensive margin, we find robust evidence that students enroll in more credits. We view this finding as consistent with the idea that laid-off students have a lower opportunity cost to investing in their education. On the extensive margin, we find little evidence of any impact on enrollment status overall. This suggests that either students' enrollment decisions do not depend on employment opportunities (but the intensity of enrollment does) or several conflicting forces balance each other out. For example, perhaps both opportunity costs and credit constraints are important and these two channels exactly cancel each other out. We also find no evidence of a change in GPA as a result of the layoff and similarly do not find evidence of a change in borrowing.

The remainder of the paper is organized as follows: the next section lays out a conceptual framework for how to think about educational investment decisions in the context of being laid off and reviews the relevant literature. We next describe the data and the empirical strategies we utilize to identify the causal impact of layoffs on student outcomes. We then discuss the results of our analysis and their robustness to several differing identification strategies. Finally, we conclude with a discussion of how our results fit into the broader literature on job loss.

\section{Conceptual Framework}

The impact of losing one's job on educational choices is ambiguous from a theoretical perspective. If students are credit constrained, the impact of job loss is likely to lead to a reduction in educational investments. It is well documented that losing one's job is associated with substantial earnings losses (JLS), which could potentially introduce 
or worsen credit constraints of working students. Even for individuals who are able to find a new job and see no drop in their wages, any period of unemployment is likely to reduce their level of wealth.

A large literature attempts to evaluate the impact of credit constraints on investment in higher education (Lang, 1993; Card, 1995; Cameron and Heckman, 2001; Keane and Wolpin, (2001); Stinebrickner and Stinebrickner, 2008; Lochner and MongeNaranjo, 2011). This literature remains sharply divided, with some studies finding that credit constraints play an important role for students from low-income families, while other studies find that credit constraints are unimportant in terms of both initial enrollment and persistence in college. While the federal student loan system does provide considerable access to loans to finance tuition and school-related expenses, the full cost of attending college can rise beyond what students are able to borrow from the federal government (Goldrick-Rab, 2016), meaning that some students may need to turn to the less generous private loan market (where credit approval is not guaranteed) and/or labor earnings to finance their time in college.

As discussed in Becker (1975), college investment decisions depend on a student's opportunity cost of time. Empirically this relationship has been confirmed, typically measuring the opportunity cost of time as some form of high school graduates average wage (Kane, 1994; Rouse, 1994). When considering the education decisions of laid-off workers purely from an opportunity cost of time perspective, we would expect to see an increase in the educational investment since their opportunity cost has decreased.

An important parameter when considering the opportunity cost of investing in one's education is the discount rate of future earnings. In our context, individuals who 
respond to a layoff by altering their educational investment decisions would be likely to have a relatively high discount rate, since earnings while enrolled in college represent a small share of total lifetime earnings. We will briefly return to this point when we examine heterogeneity across various subgroups in the response to being laid off.

Based on the above arguments, it is clear that there is no theoretical or empirical consensus on how students' educational choices might respond to being laid off. Our paper aims to fill this hole and provide the first evidence on this relationship.

\section{Data}

We utilize two administrative data sources from the state of Ohio to study the linkage between job loss and educational outcomes. ${ }^{2}$ The first dataset provides transcript data for all students attending an Ohio public higher education institution, and spans the academic years starting in 2000-2010. ${ }^{3}$ The second dataset includes Unemployment Insurance (UI) data on both firms and workers between 2003 and 2012. These data are made available to researchers by the Ohio Educational Research Data Center (OERDC) and include data from the Ohio Workforce Data Quality Initiative (OWDQI).

The wage and employer data come from the Ohio Department of Job and Family Services and include Quarterly Census of Employment and Work (QCEW) enterprise level data as well as worker-level quarterly earnings data. The higher education data includes the universe of two- and four-year public college enrollment in Ohio. With the

\footnotetext{
${ }^{2}$ Some of the text describing the dataset comes from our previous work using the same dataset (Ost, Pan and Webber 2016)

${ }^{3}$ While we can observe every course attempted, the data aggregate student performance to the student-by-semester level so that we can observe semester GPA, but not individual course grades.
} 
exception of federal workers and the self-employed, the UI data covers the universe of workers in Ohio.

We impose several sample restrictions on both the higher education and UI data. First, we restrict the sample to students whose date of first enrollment occurs during a fall semester between 2000 and 2010. Second, we focus our attention on students who attempt at least four credits in their first term. Third, we restrict the UI earnings data to payments of at least $\$ 500$ per quarter and we focus on each worker’s primary employer for each quarter as measured by total quarterly pay from each employer. ${ }^{4}$

While our data does not have a direct measure of layoff, we follow a long literature using administrative data to study layoff and infer layoff status from the data. We deem a firm to have had a mass layoff event if it satisfies two conditions simultaneously: (1) there was a quarter-to-quarter drop in employment of at least 30 percent, (2) there was a year-to-year drop in employment of at least 30 percent. While we follow past work by requiring a 30 percent quarter-to-quarter employment drop, our definition represents a higher bar for identifying mass layoff than has been used in the prior literature because we also require the year-to-year employment drop. This higher bar suggests that we are less likely to falsely classify a firm as having a mass layoff (but are also more likely to fail to identify true mass layoff events). This restriction suggests that our estimates apply most directly to relatively more severe mass-layoffs.

\footnotetext{
${ }^{4}$ We drop small quarterly payments because the UI data include any payment from a firm to an individual, even in cases where that payment would not constitute what we normally think of as a job (e.g. legal payment, consulting service, etc.). For related reasons, we also only use an individual's "dominant job" (highest earning) in earnings calculations in the event that they work for multiple employers in the same quarter. These restrictions are standard when using UI data; see Webber (2015) as an example and for further citations.
} 
The second condition, requiring at least a 30 percent drop in employment relative to the same quarter in the prior year, is particularly important for our context. This condition rules out the misclassification of mass layoff events due to a high degree of seasonality in a firm's workforce. Given the prevalence of "summer jobs" that students likely work at, not imposing this condition could potentially identify a local YMCA as having a mass layoff event every fall quarter.

Despite the richness of these datasets, there are several limitations of the data for the purposes of our study. First, we cannot observe enrollment at any private institutions or at public institutions outside of the state of Ohio. Thus, to the extent that job loss impacts students at private schools in a different way than their public school counterparts, we will not capture this effect. For instance, if private school students are on average more constrained by income because of the typically higher tuition, this will not be reflected in our findings. Second, we are not able to distinguish between students leaving our sample and transferring to private or out-of-state schools. If layoff increases the probability of transfer, this will lead our estimates of the enrollment effect to be upwardly biased. Third, we cannot distinguish between leaving the state, working for the federal government, being self employed and not working.

Table 1 presents descriptive statistics on some basic demographic and academic characteristics for three samples of students: all students, students working during their first year, and students who experience a mass layoff either in their first or third year. The three samples are broadly similar in terms of their demographics, although there are some substantively important differences. For example, women and students who attend a two-year college make up a larger share of the working student and layoff samples. 


\section{Empirical approach}

The empirical literature on the effects of job loss has long utilized mass layoff events as its identifying source of variation (Jacobsen et al. 1993). The logic is that separations from employment are often not exogenously determined, with a worker deciding to quit because they are unhappy with their current situation or being fired due to low productivity (or a multitude of other reasons which could be correlated with unobservable productive characteristics). We similarly focus our analysis on workers who separate as part of a mass layoff because traditional quits or firings are certainly not exogenous to educational decisions (e.g. a worker may quit their job in order to focus on their studies).

Moreover, because firms that experience a mass layoff event may be different along unobservable dimensions than firms that do not, comparing laid off workers to the general working population could conflate the impact of losing one's job with these omitted variables. In light of these potential threats to identification, we discuss below three distinct research designs that could be utilized to study the impact of being at a firm that has a mass layoff on educational outcomes. We describe each of the three designs in terms of the treatment and control groups used to identify the impact of layoff. For all three designs, our key outcomes of interest are measured during the fall term of the $2^{\text {nd }}$ year. As such, the enrollment outcome measures whether students persist to the second year, a common metric for evaluating colleges.

\section{Design \#1:}

Treatment Group: Students who are laid off (leaving firm during a quarter determined as a mass layoff event) during their first year of school. 
Control Group: Students who work continuously during their first year of school and have no layoff exposure in their first year.

On ex-ante grounds, there is reason to doubt that workers who are not laid off provide a good control group for laid off workers. The identifying assumption for this design is that being laid off is entirely exogenous to worker characteristics. As it relates to educational decisions, an employer might decide to lay off an individual who has expressed an interest in scaling back their work in order to focus more on their studies, which adds another layer of potential bias in addition to the usual unobserved ability bias that we would be concerned with in this design. While there are many reasons to be concerned about comparisons of laid-off and continuously employed student workers, we show specifications using this design to establish baseline estimates.

\section{Design \#2:}

Treatment Group: Students working at a firm that has a mass layoff event during their first year of school.

Control Group: Students working at a firm that does not have a mass layoff event during first year of school.

This strategy is effectively an intent-to-treat (ITT) model which sidesteps the issue of individuals being laid off endogenously by focusing on the outcomes of all workers at mass-layoff firms, whether they are laid off or not. While this design likely utilizes a more exogenous source of variation than does the first design, it is still possible that firms that have a mass layoff event are systematically different than those which do not. For example, if firms with a high probability of mass layoffs are viewed as less desirable by potential employees, then more able workers (who might also be more 
invested in their studies) would be more likely to work at firms in this design's control group.

\section{Design 3:}

Treatment: Students working at a firm during their first year enrolled in school where that firm will have a mass layoff event during their first year enrolled in school.

Control: Students working at a firm during their first year enrolled in school where that firm will have a mass layoff event during their third year enrolled in school.

This strategy retains the ITT design from above, but compares workers at firms that experience a mass layoff event in their first year of school to similar workers at firms that do not experience such a layoff event until the third year. ${ }^{5}$ In this way, we attempt to isolate only the most similar workers and firms to obtain the causal effect of layoffs on student outcomes. The outcomes are measured during the second academic year of school. Importantly, both treatment and control are working during their first year of school at the type of firm that has mass layoff events. The variation used to identify the impact of mass layoffs is thus generated by the timing of when the mass layoff occurs in an individual's educational career. Importantly, in defining the control group, we do not require that the student worker is still working at the firm during their third year and thus, some students in the control group are not actually exposed to a mass layoff at all.

Each of the three empirical designs requires a different assumption. Design 1 assumes that conditional on covariates, individual-level layoff is exogenous. Design 2

\footnotetext{
${ }^{5}$ The treatment group in Design 2 and Design 3 are not exactly same because in Design 3 we drop individuals working at firms that have mass-layoffs in both their first year and a subsequent year to ensure that students cannot be part of both the treatment and control groups. Repeated layoffs are fairly common since firm financial distress tends to be serially correlated over time.
} 
assumes that conditional on covariates, firm-level layoff is exogenous. Design 3 assumes that conditional on covariates, the timing of firm-level layoffs is exogenous. While it is not possible to directly test any of these assumptions, examining observable differences between treatment and control provides suggestive evidence on unobservable differences. As such, our first step towards evaluating the credibility of each design is to compare the observable characteristics of the treatment and control in each of the three designs.

Table 2 presents tests of covariate balance across the three strategies described above. The first two panels (corresponding to Designs 1 and 2) show modest differences in the demographic and academic covariates between the treatment and control groups. Nevertheless, many of these differences are statistically significant and some differences are substantively important. While this alone would not necessarily lead to bias in our results (because we can control for all the variables shown in Table 2), these results are suggestive of differences along unobservable dimensions between the treatment and control groups. By contrast, Design 3 (third panel) shows no statistically significant differences between the treatment and control groups, suggesting that it utilizes the most plausibly exogenous variation available to us.

Although the treatment and control group appear quite comparable for Design 3, we still control for covariates in order to increase precision. In each model, we control for age at entry, race, gender, hours attempted during the first term enrolled, GPA during first term enrolled, and earnings during first term enrolled, as well as cohort, year, and institution fixed effects.

\section{Results}


While we view Design 1 as less credible on ex-ante grounds than either Design 2 or Design 3, one important difference is that Design 1 provides an estimate of the impact of layoff whereas Design 2 and 3 provide estimates of the impact of working at a firm with a mass layoff. In order to get a sense of how to compare estimates from Design 1 to estimates using the other designs, it is useful to estimate the impact of firm-level layoff on the probability of individual level layoff. Table 3 presents estimates of the effect of being at a firm which experiences a mass layoff event on the likelihood of being laid off as an individual. If one were to instrument for individual-level layoff using firm-level layoff, then the results shown in Table 3 would be the first stage estimate for this regression. As such, in order to compare the Design 1 estimates to the ITT estimates from the other two designs, one might scale the ITT estimates by $1 / 0.7$. However, applying this scaling would make the (likely unreasonable) assumption that only the laidoff individuals are impacted by the firm-level layoff. In practice, workers who survive a mass layoff event are likely directly impacted by the event. Therefore, although we believe that we can credibly identify the impact of working at a firm that suffers a mass layoff event, scaling this estimate by $1 / 0.7$ to identify the causal impact of individual layoff may lead to overstating the impact of individual layoff. Put another way, although we credibly estimate the reduced form impact of firm-level layoff, we do not think that firm-level layoff is a valid instrument for individual-level layoff.

Before turning to our educational outcomes, we first look at labor market outcomes in the term following the layoff event. Because we view Design 3 as ex-ante the most credible, our main tables present results based on this design and we show results from the other two designs in the appendix. We are unable to perfectly measure 
whether an individual is employed during the fall semester because quarterly earnings information does not line up with the academic schedule. To match employment outcomes as closely as possible to the fall semester of the $2^{\text {nd }}$ year when the academic outcomes are measured, we measure employment outcomes based on the $4^{\text {th }}$ quarter (October-December). ${ }^{6}$

Table 4 presents the impact of our layoff measure on both employment and log weekly earnings (conditional on being employed). ${ }^{7}$ We find a roughly six percentage point decline in the likelihood of being employed and small earnings impacts in the models with full sets of control variables. While inherently untestable, the fact that we see considerable stability in the estimated coefficients as control variables are added provides some suggestive evidence against the possibility of unobservable selection driving differences between the treatment and controls groups for Design 3.

While previous work has generally found a negative earnings impact following job loss, there are several reasons that one might expect a smaller earnings effect for our sample. First, firm-specific human capital has been one of the key theoretical rationales used to explain the negative earnings results in the prior literature. Given that our sample is disproportionately younger and earlier in their careers than samples utilized in prior

\footnotetext{
${ }^{6}$ Students who work during September but cease to work prior to October will be misclassified as not working during the fall term. Similarly, for both treatment and control, employment during winter break may be counted as employment while enrolled in college. We view this measurement error as unlikely to substantially bias our estimates since the issue will impact both the treatment and control groups similarly. Furthermore, our results are robust to restricting the employment outcome to those that work at least 4 weeks during the $4^{\text {th }}$ quarter to address the possibility of misclassifying winter-break employment.

${ }^{7}$ Earnings results unconditional on employment are of course negative due to the negative relationship between our layoff measure and employment. These results are available upon request.
} 
research, specific capital is likely less of a factor in our setting. Second, given their young age, our sample would also be more likely (relative to the prior literature) to work at jobs where the minimum wage is binding, which would prevent sizable earnings losses (conditional on employment).

Appendix Tables 1a and 1b show estimates analogous to Table 4, but using Designs 1 and 2. Using Design 2, the employment estimates are very similar to those in our preferred specification but the earnings estimates are larger and are statistically significant. Using Design 1, our results are qualitatively similar to Design 2 and if we scale the ITT estimates by $1 / 0.7$, the implied estimates are fairly similar in magnitude as well. The broad consistency of the results across the three different designs suggests that the potential limitations of Designs 1 and 2 do not lead to substantially biased estimates of the direct labor market effects of layoff for working students.

As discussed above, the theoretical impact of layoff on individuals' educational outcomes is ambiguous. For those students who are credit constrained, losing a job would likely lead to reduced educational investment. On the other hand, those workers whose primary constraint is time may increase their educational investment following an unanticipated layoff. Table 5 shows that the net effect is an increase in educational investments. Notably, the extensive margin impact (enrollment) is a fairly precisely estimated zero. The increased investment appears to only take place along the intensive margin (credits attempted), reflecting an opportunity cost mechanism.

Appendix Tables 2a and 2b report the results utilizing Designs 1 and 2, respectively. While the estimates based on Design 1 and Design 2 are somewhat more sensitive to which controls are added, broadly, these designs confirm our estimates using 
Design 3. Of particular note is the similarity of the credits attempted results across all three methods despite considerable differences in the identifying variation used. This is especially important when comparing Designs 2 and 3. While Design 3 seems to us to use the most exogenous source of variation, one criticism of this design is that workers or firms who anticipate the layoff could introduce bias into our estimates. Design 2, conversely, would not be biased from an anticipatory response because the control group is never laid off. Although the three designs show broadly similar results, one difference is that Designs 1 and 2 suggest some evidence of a reduction in enrollment at the extensive margin. We view this as likely reflecting unobserved differences between treatment and control as opposed to reflecting a true causal effect, both because Design 3 shows no such effect and because the extensive margin estimates are fairly sensitive to controls. $^{8}$

One data limitation of our study relative to the literature on working students is the lack of an hours worked variable in our dataset. Prior work (Ehrenberg and Sherman, 1987) has identified a strong negative relationship between educational outcomes and working a substantial number of hours each week (i.e. more than 15-20), with possible beneficial effects of working a small number of hours. With this limitation, our conclusions can only be generalized to the average working student, with the caveat that there may be heterogeneous effects by hours worked.

\footnotetext{
${ }^{8}$ To the extent that there really is an enrollment effect, this raises the possibility that the intensive margin estimates are biased by sample selection since those estimates are necessarily conditional on enrollment. That said, we suspect that any bias from this source is likely to be unimportant since the enrollment point estimates shown in Tables $2 \mathrm{a}$ and $2 \mathrm{~b}$ are quite small.
} 
While the statistical evidence of a qualitative increase in educational investment following a layoff is convincing, the magnitude is much more difficult to interpret. Since we estimate intent-to-treat models, the estimated coefficients are effectively lower bounds which should be scaled up in order to obtain the impact for a given individual. The problem is that the two available options by which we could scale our estimates both require strong assumptions. We could scale the coefficients in Table 5 by those from Table 3, which would theoretically yield the impact of being laid off. However, this would make the implicit assumption that workers who are not laid off are not impacted by the layoff event, which seems unlikely, given that workers who remain could have lower wages, increased workloads, or face increased stress from job-related uncertainty.

Alternatively, it may also seem reasonable to scale the estimates in Table 5 by the probability that an individual loses their job and does not find a new one (Table 4). This would be akin to a LATE for individuals who experience the worst employment consequences of a layoff, and would lead to considerably higher estimated effects (estimates scaled by 1/0.06). However, this calculation would assume that the educational impact operates entirely through the channel of employment, which seems unreasonable given potential impacts of layoff on wealth, wages, employment search or health. In order to not overstate our results, we prefer to interpret the estimates in Table 5 as clear qualitative evidence that the net effect of being laid off is an increased investment in education, but leave it to the reader to determine the preferred assumption with which to scale these numbers.

Working at a firm that experiences a mass layoff event appears to have negligible effects on other educational outcomes. Table 6 presents the estimated ITT impacts on 
GPA and financial aid status. We might have expected to see a decrease in GPA because of stress related to job uncertainty, but perhaps this is balanced by a relaxation of time constraints. Our results are consistent across the various designs reported in the Appendix. In unreported analyses, we similarly find no impact on Pell Grant receipt, work study status, and various other financial aid metrics.

Table 7 reports ITT estimates for a variety of outcomes broken down by demographic and academic categories. Each entry in the table corresponds to the coefficient, standard error, and sample size from a regression including all of our available controls run exclusively on the associated group. There is little evidence of heterogeneous treatment effects for most outcomes and along the majority of demographic subgroups. We find that the individuals most likely to increase their educational investment through additional credit hours are those at 2-year schools and particularly older students (age 25 and over). Furthermore, there is some evidence of an increase in GPA for affected workers over age 25, again consistent with the opportunity cost channel. Finding an increase in credits attempted for older individuals is consistent with the notion that these students face more time constraints than do other students.

We are not able to look at long-term outcomes such as degree receipt with Design 3 since in the long-run both the treatment and control groups become treated. We can, however, use Design 2, where we compare students working at firms with a mass layoff to students working at firms that do not have a mass layoff. Table 8 shows no relationship between layoff and degree completion at either a 2- or 4-year school. We view this as suggestive, but not definitive evidence because of the additional assumptions required to interpret Design 2 as causal. It is worth noting, however, that Designs 2 and 3 
yield very similar results on the whole for the earlier outcomes where both are viable strategies.

\section{Discussion}

Several striking results deserve further discussion. First, we find a precisely estimated zero effect on the probability of receiving financial aid and in results not shown, we also find a precisely estimated zero effect on the amount of financial aid received. Given that students are less likely to be employed following the layoff and enroll in more credits, it is surprising that they do not borrow more following a layoff. While we have no definitive explanation for this result, one possibility is that students increase borrowing along unmeasured dimensions such as informal person-2-person borrowing or credit card debt. ${ }^{9}$ Second, we find an increase on the intensive, but not the extensive margin of college enrollment. The increase in credits attempted likely reflects the lower opportunity cost of college as employment declines. The lack of an extensive margin effect could suggest that extensive margin decisions are unaffected by employment, but it could also reflect the combination of two forces that balance each other out. In particular, relative to the intensive margin, we expect that credit constraints may be more likely to bind at the extensive margin and so the credit constraint channel may balance out the opportunity cost channel on the extensive, but not the intensive margin.

\footnotetext{
${ }^{9}$ It is also possible that students could use their savings to pay for college, but we suspect that few working college students would have sufficient savings to pay for the full cost of college.
} 
Our most direct contribution is understanding the impact of layoff on educational outcomes, but through the study of that question, we also provide indirect evidence on the general impact of working during college. Layoff during the $1^{\text {st }}$ academic year reduces employment in the fall of the $2^{\text {nd }}$ academic year, and if this were the only channel through which layoff impacts academic outcomes, we could use layoff as an instrument to help estimate the impact of working during college on academic outcomes. This strategy is not possible because layoff likely has a direct impact on other intermediate outcomes that we are unable to measure. For example, we suspect that many laid-off students are searching for a job following the layoff and so non-employed laid off students are not engaged in the same activity as non-employed students in general. While other channels potentially exist, we suspect that layoff impacts academic outcomes principally by reducing employment, decreasing wealth, increasing job search intensity and by increasing stress. Since we only identify the combined effect of layoff on academic outcomes, it is not possible to definitively separate out the effect caused by reduced employment from these other factors. That said, we expect that all of the other channels through which layoff might impact academic outcomes would negatively affect educational investment and performance. As such, our results provide suggestive evidence that reduced employment contributes to increased credits attempted since this is the only factor where there is a theoretical basis to expect a positive effect. Naturally, this logic relies heavily on our priors regarding the likely direction through which the nonemployment channels will impact academic investment and so we do not push this point strongly. 


\section{Conclusion}

We provide the first evidence on the link between job loss and educational decisions for working students, using linked employer-employee data matched with transcript-level data from each Ohio public 2- and 4-year college.

Our identification strategy focuses only on workers who work at a firm that experiences a mass layoff event, and uses variation in the timing of such an event to estimate the impact on educational outcomes. We find robust evidence that experiencing a mass layoff event leads to increased investment in education on the intensive margin (credits attempted). We find little evidence of a discernable impact on other educational outcomes such as GPA or financial aid status. The impacts are chiefly concentrated among individuals at 2-year institutions and older students.

The results discussed above provide the first evidence on the impact of job loss on human capital investment decisions. Despite a large literature that studies the consequences for workers following mass layoff events, little was previously known about the effect on educational outcomes. Our findings are consistent across three distinct identification strategies that utilize substantially different sources of variation, lending credence to the validity of our findings.

Taken together, the above results paint a picture of the typical student worker being relatively more time constrained (as opposed to credit constrained). As the opportunity cost of students' time falls, students invests more heavily in their education. This result is important to economists interested in the impact of job loss, researchers interested in the relationship between work and education, and education policymakers. 


\section{References:}

Ashenfelter, Orley. "Estimating the effect of training programs on earnings." The Review of Economics and Statistics (1978): 47-57.

Becker, Gary S. Human capital: A theoretical and empirical analysis, with special reference to education. University of Chicago Press, 2009.

Berger, Mark C., and Thomas Kostal. "Financial resources, regulation, and enrollment in US public higher education." Economics of Education Review21.2 (2002): 101-110.

Betts, Julian R., and Laurel L. McFarland. "Safe port in a storm: The impact of labor market conditions on community college enrollments." Journal of Human

Resources (1995): 741-765.

Brand, Jennie E., Becca R. Levy, and William T. Gallo. "Effects of layoffs and plant closings on

subsequent depression among older workers." Research on aging 30.6 (2008): 701-721.

Card, David “Earnings, Schooling and Ability Revisited,” Research in Labor Economics, Vol. 14, 1995, pp. 23-48.

Card, David, and Thomas Lemieux. "Dropout and enrollment trends in the postwar period: What went wrong in the 1970s?." Risky behavior among youths: An economic analysis. University of Chicago Press, 2001. 439-482.

Cameron, Stephen V and Heckman, James J. “The Dynamics of Educational Attainment for Black, Hispanic, and White Males,” Journal of Political Economy, vol. 109, pp. 45599, 2001.

Charles, Kerwin Kofi, and Melvin Stephens Jr. "Job Displacement, Disability, and Divorce." Journal of Labor Economics 22.2 (2004).

Couch, Kenneth A., and Dana W. Placzek. "Earnings losses of displaced workers revisited." The American Economic Review 100.1 (2010): 572-589.

Davis, Jessica. "School enrollment and work status: 2011." American Community Briefs (2012): 11-14.

Ehrenberg, Ronald G., and Daniel R. Sherman. "Employment while in college, academic achievement, and postcollege outcomes: A summary of results." Journal of Human Resources (1987): 1-23.

Frenette, Marc, Richard Upward, and Peter W. Wright. "The Long-term Earnings Impact of Post-secondary Education Following Job Loss." Statistics Canada Analytical Branch Studies Working Paper 334 (2011). 
Goldrick-Rab, Sara and Nancy Kendall. “The Real Price of College” The Century Foundation: College Completion Series Part 2 (2016) 1-26.

Häkkinen, Iida. "Working while enrolled in a university: does it pay?." Labour Economics 13.2 (2006): 167-189.

Hallock, Kevin, F., Michael R. Strain, and Douglas A. Webber "Job Loss and Effects on Firms and Workers,” Chapter 1 in Cary Cooper, Alankrita Pandey, and James Quick Eds, Downsizing: Is Less Still More?, Cambridge University Press, 2012.

Hilger, Natnaniel, G. “Parental Job Loss and Children’s Long-Term Outcomes: Evidence from 7 Million Fathers’ Layoffs” American Economic Journal: Applied Economics, Forthcoming.

Hotz, V. Joseph, et al. "Are there returns to the wages of young men from working while in school?." Review of Economics and statistics 84.2 (2002): 221-236.

Jacobson, Louis S., Robert J. LaLonde, and Daniel G. Sullivan. "Earnings losses of displaced workers." The American economic review (1993): 685-709.

Kane, Thomas J. "College entry by blacks since 1970: The role of college costs, family background, and the returns to education." Journal of political Economy (1994): 878-911.

Keane, Michael, and Wolpin, Ken, “The Effect of Parental Transfers and Borrowing Constraints on Educational Attainment,” The International Economics Review, 42(4), 2001.

Lang, Kevin. "Ability bias, discount rate bias and the return to education."Unpublished Manuscript, Boston University (1993).

Lochner, Lance and Alexander Monge-Naranjo. "The Nature of Credit Constraints and Human Capital," American Economic Review. (2011): 101(6), pages 2487-2529.

Ost, Ben, Weixiang Pan, and Douglas A. Webber. "The Returns to College Persistence for Marginal Students: Regression Discontinuity Evidence from University Dismissal Policies." (2016).

Rouse, Cecilia Elena. "What to do after high school: The two-year versus four-year college enrollment decision." Choices and consequences: Contemporary policy issues in education (1994): 59-88.

Stinebrickner, Ralph, and Todd R. Stinebrickner. "Working during school and academic performance." Journal of labor Economics 21.2 (2003): 473-491. 
Stinebrickner, Ralph, and Todd Stinebrickner. "The Effect of Credit Constraints on the College Drop-Out Decision: A Direct Approach Using a New Panel Study." The American Economic Review 98.5 (2008): 2163-2184.

Sullivan, Daniel, and Till Von Wachter. "Job displacement and mortality: An analysis using administrative data." The Quarterly Journal of Economics(2009): 1265-1306.

Webber, Douglas A. "Firm market power and the earnings distribution."Labour Economics 35 (2015): 123-134. 
Table 1: Summary Statistics

\begin{tabular}{lrrrrrr}
\hline & \multicolumn{2}{c}{ All students } & \multicolumn{1}{c}{ Working students } & \multicolumn{2}{c}{ Layoff sample } \\
\cline { 2 - 7 } Demographic variables & \multicolumn{1}{c}{ Mean } & Std. Dev. & Mean & Std. Dev. & Mean & Std. Dev. \\
$\quad$ & & & & & & \\
Age at entry & 21.1688 & 6.1609 & 21.2205 & 5.9735 & 21.2351 & 5.9348 \\
Black or Hisp. & 0.1505 & 0.3575 & 0.1320 & 0.3385 & 0.1495 & 0.3566 \\
Female & 0.5288 & 0.4992 & 0.5615 & 0.4962 & 0.5701 & 0.4951 \\
Two-year college & 0.4625 & 0.4986 & 0.5453 & 0.4979 & 0.5465 & 0.4978 \\
$1^{\text {st }}$ term academic variables & & & & & & \\
Credit hours attempted & 12.0527 & 3.8306 & 11.6010 & 3.8724 & 11.5676 & 3.9183 \\
GPA & 2.5642 & 1.1496 & 2.5159 & 1.1579 & 2.4922 & 1.1611 \\
Have financial aid & 0.6953 & 0.4603 & 0.6644 & 0.4722 & 0.6783 & 0.4672 \\
Total Financial aid amount & 2977.08 & 3159.19 & 2441.78 & 2695.39 & 2425.35 & 2688.60 \\
N & 556,923 & & 318,375 & & 31,975 & \\
\hline
\end{tabular}

Each column contains data on all students at public postsecondary institutions in the state of Ohio between 2000 and 2010 who attempted at least 4 credits in their first semester of college.

Table 2: Tests of Covariate Balance 


\begin{tabular}{llllll}
\hline \hline \multicolumn{2}{l}{ Design 1: Students laid off in 1st year vs those continuously employed } & & \\
\hline & $(1)$ & $(2)$ & $(3)$ & $(4)$ & $(5)$ \\
Demographic Variables & Control & Treatment & $(2)-(1)$ & SE & P-value \\
Age at entry & 21.3508 & 21.2854 & 0.0655 & 0.0403 & 0.1044 \\
Black or Hisp. & 0.1234 & 0.1443 & -0.0209 & 0.0022 & 0.0000 \\
Female & 0.5711 & 0.5783 & -0.0072 & 0.0033 & 0.0267 \\
Two-year college & 0.5731 & 0.5306 & 0.0426 & 0.0033 & 0.0000 \\
$1^{\text {st }}$ term academic variables & & & & & \\
Credit hours attempted & 11.4366 & 11.6120 & -0.1755 & 0.0253 & 0.0000 \\
GPA & 2.5442 & 2.5112 & 0.0330 & 0.0075 & 0.0000 \\
Have financial aid & 0.6514 & 0.6751 & -0.0237 & 0.0057 & 0.0000 \\
Total Financial aid amount & 2326.8776 & 2491.0011 & -164.1236 & 31.6937 & 0.0000 \\
Initial earnings & 3354.7378 & 3241.2853 & 113.4525 & 19.3578 & 0.0000 \\
N & 229918 & 25770 & & & \\
\hline
\end{tabular}

Design 2: Students working in a firm laying off in the first year vs other working students

\begin{tabular}{llllll}
\hline & $(1)$ & $(2)$ & $(3)$ & $(4)$ & $(5)$ \\
Demographic Variables & Control & Treatment & $(2)-(1)$ & SE & P-value \\
Age at entry & 21.1971 & 21.4842 & -0.2871 & 0.0387 & 0.0000 \\
Black or Hisp. & 0.1302 & 0.1521 & -0.0219 & 0.0022 & 0.0000 \\
Female & 0.5611 & 0.5659 & -0.0048 & 0.0032 & 0.1377 \\
Two-year college & 0.5473 & 0.5234 & 0.0239 & 0.0032 & 0.0000 \\
$1^{\text {st }}$ term academic variables & & & & & \\
Credit hours attempted & 11.6023 & 11.5857 & 0.0166 & 0.0251 & 0.5075 \\
GPA & 2.5161 & 2.5132 & 0.0029 & 0.0075 & 0.6997 \\
Have financial aid & 0.6630 & 0.6779 & -0.0149 & 0.0055 & 0.0066 \\
Total Financial aid amount & 2428.1124 & 2573.9230 & -145.8106 & 31.3781 & 0.0000 \\
Initial earnings & 3166.0511 & 3304.4011 & -138.3500 & 18.7730 & 0.0000 \\
N & 292395 & 25980 & & & \\
\hline
\end{tabular}

Design 3: Students working in a firm laying off in the first year vs the third year

\begin{tabular}{llllll}
\hline & $(1)$ & $(2)$ & $(3)$ & $(4)$ & $(5)$ \\
Demographic Variables & Control & Treatment & $(2)-(1)$ & SE & P-value \\
Age at entry & 21.2185 & 21.2499 & -0.0314 & 0.0666 & 0.6371 \\
Black or Hisp. & 0.1476 & 0.1512 & -0.0036 & 0.0041 & 0.3806 \\
Female & 0.5706 & 0.5697 & 0.0009 & 0.0056 & 0.8655 \\
Two-year college & 0.5460 & 0.5470 & -0.0010 & 0.0056 & 0.8585 \\
$1^{\text {st }}$ term academic variables & & & & & \\
Credit hours attempted & 11.5659 & 11.5691 & -0.0032 & 0.0439 & 0.9424 \\
GPA & 2.4913 & 2.4929 & -0.0016 & 0.0130 & 0.9021 \\
Have financial aid & 0.6776 & 0.6788 & -0.0012 & 0.0110 & 0.9102 \\
Total Financial aid amount & 2430.9611 & 2421.1283 & 9.8328 & 63.1195 & 0.8762 \\
Initial earnings & 3230.2813 & 3239.7415 & -9.4602 & 33.4068 & 0.7770 \\
$\mathrm{~N}$ & 15034 & 16941 & & & \\
\hline
\end{tabular}


Table 3: Impact of Treatment on Individual Layoff

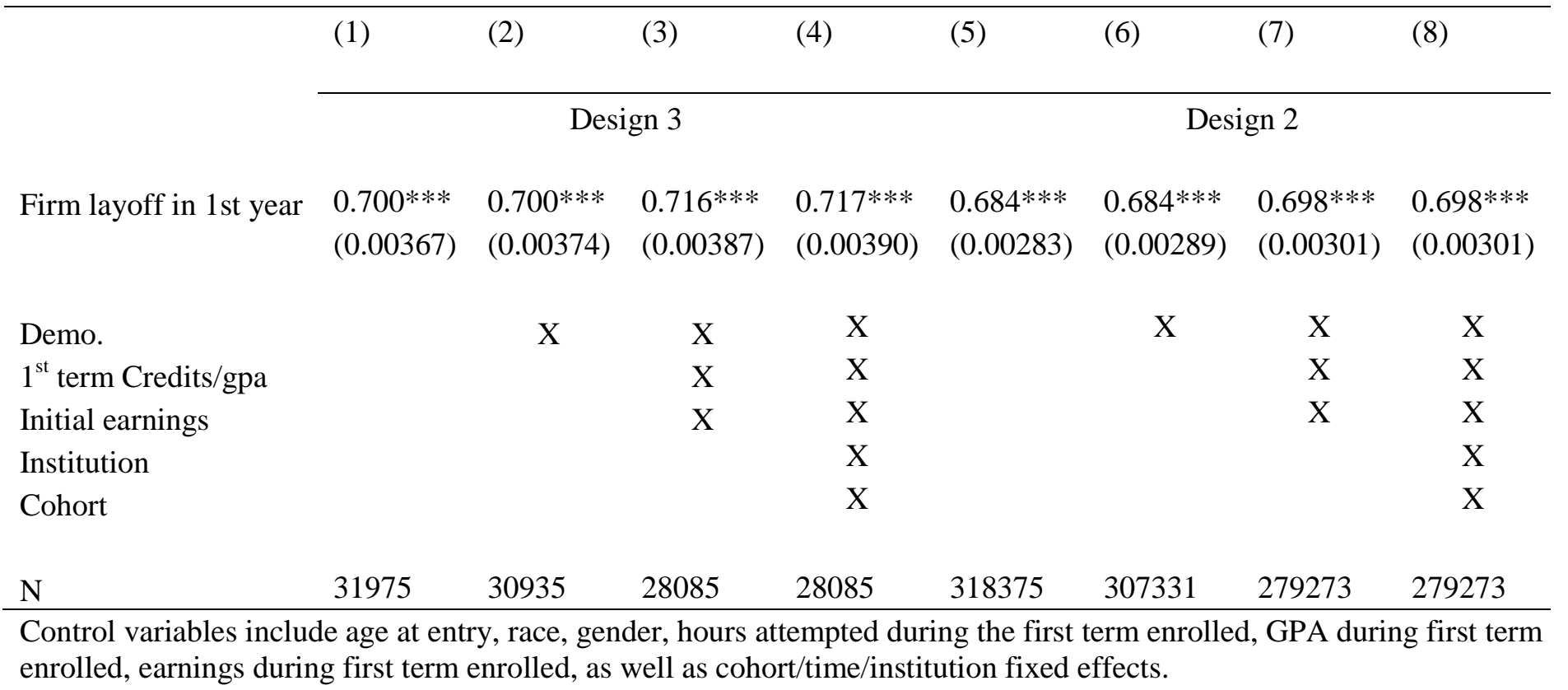


Table 4: ITT effects on employment and earnings

(1)

(2)

(3)

(4)

(5)

(6)

(7)

(8)

Employment

Log Weekly Earnings

Firm layoff in 1st year
$-0.0628 * * *$
$-0.0620 * * *$
$-0.0586^{* * *}$
$-0.0560 * * *-0.0$
$-0.0227 * * * \quad-0.0215^{* * *}$
$-0.0145$
$-0.0100$
(0.00434)
(0.00440)
(0.00448)
(0.00450)
(0.0108)
(0.0102)
(0.00950) (0.00948)

Demo.

X

$\begin{array}{ll}\mathrm{X} & \mathrm{x} \\ \mathrm{x} & \mathrm{X} \\ \mathrm{x} & \mathrm{x} \\ & \mathrm{x} \\ & \mathrm{X}\end{array}$

$\mathrm{X}$

$\begin{array}{ll}\mathrm{x} & \mathrm{x} \\ \mathrm{x} & \mathrm{x} \\ \mathrm{x} & \mathrm{x} \\ & \mathrm{x} \\ & \mathrm{x}\end{array}$

Cohort

31975

30935

28085

28085

20138

19458

17926

17926

Control variables include age at entry, race, gender, hours attempted during the first term enrolled, GPA during first term enrolled, earnings during first term enrolled, as well as cohort/time/institution fixed effects. 
Table 5: ITT on Enrollment and Credits attempted

\begin{tabular}{|c|c|c|c|c|c|c|c|c|}
\hline & (1) & (2) & (3) & (4) & (5) & (6) & (7) & (8) \\
\hline & \multicolumn{4}{|c|}{ Enrollment } & \multicolumn{4}{|c|}{ Credits Attempted } \\
\hline Firm layoff in 1st & $\begin{array}{c}0.00192 \\
(0.00557)\end{array}$ & $\begin{array}{c}0.00242 \\
(0.00561)\end{array}$ & $\begin{array}{l}-0.00348 \\
(0.00539)\end{array}$ & $\begin{array}{l}-0.00505 \\
(0.00537)\end{array}$ & $\begin{array}{c}0.118 * \\
(0.0674)\end{array}$ & $\begin{array}{c}0.146 * * * \\
(0.0656)\end{array}$ & $\begin{array}{c}0.129 * * * \\
(0.0604)\end{array}$ & $\begin{array}{c}0.134 * * * \\
(0.0583)\end{array}$ \\
\hline
\end{tabular}

Demo.

Credits/gpa at first term

Initial earnings

$\begin{array}{lll}x & x & x\end{array}$

$\mathrm{X}$

$\begin{array}{ll}\mathrm{x} & \mathrm{X} \\ \mathrm{X} & \mathrm{X} \\ \mathrm{x} & \mathrm{X} \\ & \mathrm{X} \\ & \mathrm{X}\end{array}$

Cohort

$\begin{array}{llll}31975 & 30935 & 28085 & 28085\end{array}$

17605

17063

15584

15584

Control variables include age at entry, race, gender, hours attempted during the first term enrolled, GPA during first term enrolled, earnings during first term enrolled, as well as cohort/time/institution fixed effects. 
Table 6: Effects on GPA and Financial Aid

(1) (2)

(3)

(4)

(5)

(6)

(7)

(8)

GPA Has Financial Aid

$\begin{array}{ccccccccc}\text { Firm layoff in 1st year } & 0.0330 & 0.0266 & 0.0284 & 0.0231 & 0.00979 & 0.0106 & -0.000321 & -0.00351 \\ & (0.0204) & (0.0207) & (0.0211) & (0.0216) & (0.00950) & (0.00966) & (0.00935) & (0.00914)\end{array}$

$\begin{array}{lllllllll}(0.0204) & (0.0207) & (0.0211) & (0.0216) & (0.00950) & (0.00966) & (0.00935) & (0.00914)\end{array}$

Demo.

Credits/gpa at first term

$\mathrm{X}$

$\begin{array}{ll}\mathrm{X} & \mathrm{x} \\ \mathrm{X} & \mathrm{X} \\ \mathrm{X} & \mathrm{X} \\ & \mathrm{X} \\ & \mathrm{X}\end{array}$

$\begin{array}{cc}\mathrm{X} & \mathrm{x} \\ \mathrm{X} & \mathrm{x} \\ \mathrm{X} & \mathrm{x} \\ & \mathrm{x} \\ & \mathrm{x}\end{array}$

Cohort

$\begin{array}{llll}16843 & 16330 & 14908 & 14908\end{array}$

10859

10454

9605

9605

Control variables include age at entry, race, gender, hours attempted during the first term enrolled, GPA during first term enrolled, earnings during first term enrolled, as well as cohort/time/institution fixed effects. 
Table 7: Heterogeneous Effects

(1)

2-year colleges

4-year colleges

(3)

(4)

(5)

(6)

(7)

\begin{tabular}{|c|c|c|c|c|c|c|c|}
\hline Dep. Variables & 2-year colleges & 4-year colleges & Women & Men & Age at entry $<20$ & Age at entry 21-24 & Age at entry $25+$ \\
\hline \multirow[t]{3}{*}{ Enrollment } & -0.00411 & -0.00566 & 0.00137 & $-0.0147^{*}$ & -0.00363 & -0.00575 & -0.0121 \\
\hline & $(0.00765)$ & $(0.00740)$ & $(0.00709)$ & $(0.00828)$ & $(0.00664)$ & $(0.0115)$ & $(0.0148)$ \\
\hline & 15360 & 12725 & 16161 & 11924 & 17633 & 6397 & 4055 \\
\hline \multirow[t]{3}{*}{ Employment } & $-0.0526 * * *$ & $-0.0608 * * *$ & $-0.0586 * * *$ & $-0.0537 * * *$ & $-0.0469 * * *$ & $-0.0638 * * *$ & $-0.0803 * * *$ \\
\hline & $(0.00593)$ & $(0.00688)$ & $(0.00579)$ & $(0.00716)$ & $(0.00569)$ & $(0.00946)$ & $(0.0118)$ \\
\hline & 15360 & 12725 & 16161 & 11924 & 17633 & 6397 & 4055 \\
\hline \multirow[t]{3}{*}{ Log weekly earnings } & 0.00124 & $-0.0247^{*}$ & -0.0116 & -0.00964 & -0.0129 & -0.00259 & -0.00364 \\
\hline & $(0.0123)$ & $(0.0147)$ & $(0.0122)$ & $(0.0151)$ & $(0.0121)$ & $(0.0197)$ & $(0.0234)$ \\
\hline & 9892 & 8034 & 10458 & 7468 & 11211 & 4128 & 2587 \\
\hline \multirow[t]{3}{*}{ Credits attempted } & $0.257 * * *$ & 0.0421 & $0.144^{*}$ & 0.132 & 0.0739 & 0.165 & $0.444^{* * *}$ \\
\hline & $(0.0956)$ & $(0.0716)$ & $(0.0757)$ & $(0.0912)$ & $(0.0683)$ & $(0.140)$ & $(0.173)$ \\
\hline & 6872 & 8712 & 9060 & 6524 & 10639 & 3059 & 1886 \\
\hline \multirow[t]{3}{*}{ GPA } & -0.00269 & 0.0435 & 0.0205 & 0.0241 & 0.000704 & 0.0513 & $0.101^{*}$ \\
\hline & $(0.0325)$ & $(0.0284)$ & $(0.0301)$ & $(0.0300)$ & $(0.0274)$ & $(0.0425)$ & $(0.0530)$ \\
\hline & 6413 & 8495 & 8701 & 6207 & 10227 & 2881 & 1800 \\
\hline \multirow{3}{*}{ Financial aid amount } & -57.71 & 12.01 & 45.26 & -97.29 & 30.34 & -83.61 & -122.6 \\
\hline & (41.52) & (81.78) & (61.76) & (66.90) & (56.81) & (96.73) & (120.2) \\
\hline & 5049 & 4556 & 5452 & 4153 & 5939 & 2201 & 1465 \\
\hline \multirow[t]{3}{*}{ Has financial aid } & -0.0118 & 0.00390 & 0.00988 & -0.0202 & 0.00316 & -0.00347 & -0.0363 \\
\hline & $(0.0123)$ & $(0.0134)$ & $(0.0122)$ & $(0.0138)$ & $(0.0115)$ & (0.0193) & $(0.0240)$ \\
\hline & 5049 & 4556 & 5452 & 4153 & 5939 & 2201 & 1465 \\
\hline
\end{tabular}

All specifications include controls for age at entry, race, gender, hours attempted during the first term enrolled, GPA during first term enrolled, earnings during first term enrolled, as well as cohort/time/institution fixed effects. 
Table 8: Effects on degree (design 2)

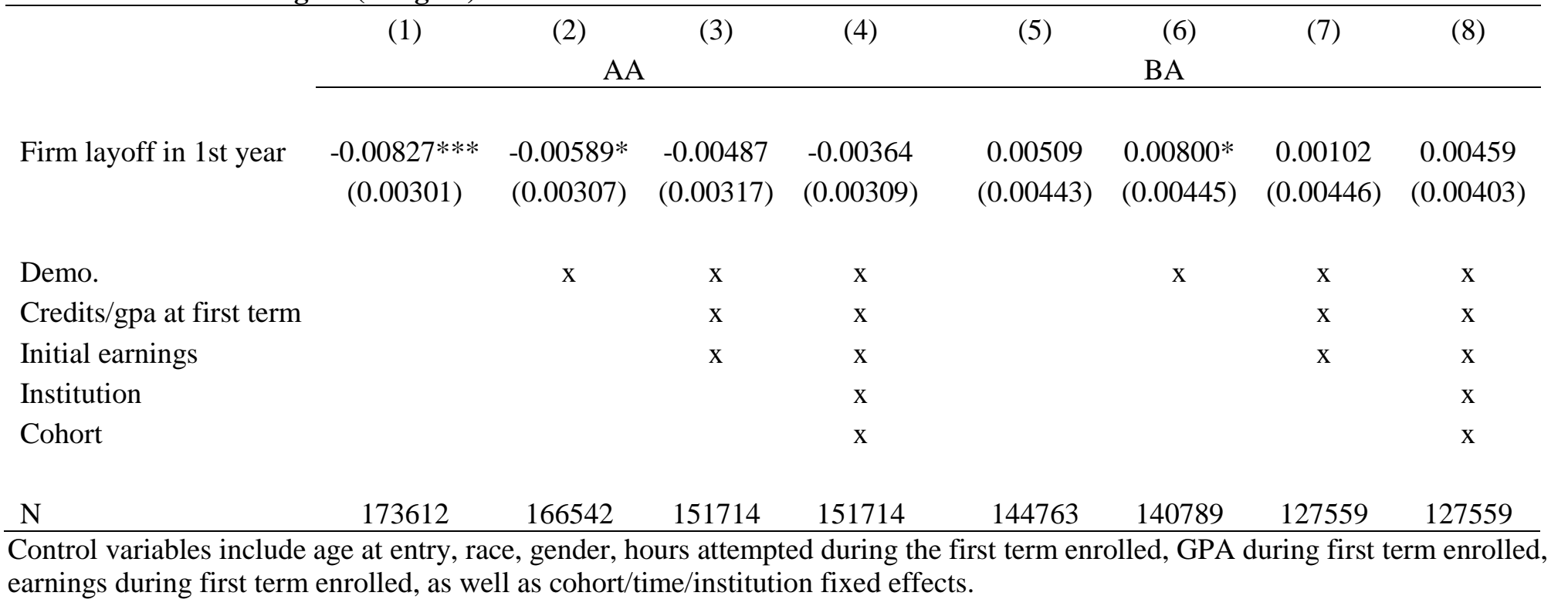


Appendix Table 1a: Effects on employment and earnings (design 1)

(1)

(2)

(4)

(5) (6)

(7)

Employment

Log Weekly Earnings

Layoff in 1st year

$$
\begin{array}{ll}
-0.115^{* * *} & -0.115^{* * *} \\
(0.003) & (0.003)
\end{array}
$$

$-0.110 * * *$

$-0.108^{* * *}$

$-0.046^{* * *}$

$-0.042 * * *$

$-0.034 * * *$

$-0.031^{* * *}$

(0.003)

(0.003)

(0.006)

(0.006)

(0.006)

(0.006)

Demo.

$\mathrm{X}$

$\begin{array}{cc}\mathrm{X} & \mathrm{X} \\ \mathrm{X} & \mathrm{X} \\ \mathrm{X} & \mathrm{X} \\ & \mathrm{X} \\ & \mathrm{X}\end{array}$

$\mathrm{x}$
$\mathrm{x}$
$\mathrm{x}$
$\mathrm{x}$

$\mathrm{x}$

$\mathrm{x}$

$\mathrm{x}$

Credits/gpa at first term

Initial earnings

Institution

Cohort

$318375 \quad 307331 \quad 279273 \quad 279273$

214303

206617

189928

189928

Control variables include age at entry, race, gender, hours attempted during the first term enrolled, GPA during first term enrolled, earnings during first term enrolled, as well as cohort/time/institution fixed effects. 
Appendix Table 1b: Effects on employment and earnings (design 2)

(1)

(2)

(4)

(5) (6)

(6) (7)

(8)

Employment

Log Weekly Earnings

Firm layoff in 1st year
$-0.0556 * * *$
$-0.0548 * * *$
$-0.0554 * * *$
$-0.0538 * * *$
$-0.0143^{* * *}$
$-0.0282 * * *$
$-0.0330 * * * \quad-0.0292 * * *$
(0.00263)
$(0.00267)$
(0.00276)
(0.00276)
$(0.00645) \quad(0.00602)$
(0.00564)
$(0.00560)$

Demo.

$\mathrm{X}$

$\begin{array}{ll}\mathrm{x} & \mathrm{x} \\ \mathrm{x} & \mathrm{x} \\ \mathrm{x} & \mathrm{x} \\ & \mathrm{x} \\ & \mathrm{x}\end{array}$

$\mathrm{X}$

$\begin{array}{ll}x & x\end{array}$

$\mathrm{x} \quad \mathrm{x}$

Initial earnings

Institution

Cohort

318375

307331

279273

279273

214303

206617

189928

189928

Control variables include age at entry, race, gender, hours attempted during the first term enrolled, GPA during first term enrolled, earnings during first term enrolled, as well as cohort/time/institution fixed effects. 
Appendix Table 2a: Enrollment and Credits attempted (design 1)

(1) (2) (3)

Enrollment

(4)

Layoff in 1st year

$\begin{array}{cccc}0.00334 & 0.00574 * & 0.00120 & -0.0136 * * * \\ (0.00328) & (0.00331) & (0.00321) & (0.00302)\end{array}$

$0.353 * * *$

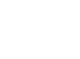

(5) (6) (7)

Credits Attempted

(8)

)

X $\quad \mathrm{X}$

$\mathrm{X}$

$\mathrm{X} \quad \mathrm{X}$

$\mathrm{X} \quad \mathrm{X}$

$\mathrm{X}$

$\mathrm{X}$

$\mathrm{X}$

$0.187 * * * \quad 0.0714 * * *$

$\begin{array}{llll}0.0407) & (0.0396) & (0.0363) & (0.0347)\end{array}$

$\mathrm{x}$

$\begin{array}{cc}\mathrm{X} & \mathrm{X} \\ \mathrm{X} & \mathrm{X} \\ \mathrm{X} & \mathrm{X} \\ & \mathrm{X} \\ & \mathrm{X}\end{array}$

Cohort

Control variables include age at entry, race, gender, hours attempted during the first term enrolled, GPA during first term enrolled, earnings during first term enrolled, as well as cohort/time/institution fixed effects. 
Appendix Table 2b: ITT on Enrollment and Credits attempted (design 2)

(1)

(2)

Enrollment

(4)

(5)

(5) (6)

(6) (7)

Credits Attempted

(8)

$\begin{array}{cccccccccc}\text { Firm layoff in 1st year } & 0.0105^{* * *} & 0.0153^{* * *} & 0.00943^{* * *} & -0.00463 & 0.129^{* * *} & 0.204^{* * *} & 0.144^{* * *} & 0.0741^{* * *} \\ & (0.00323) & (0.00326) & (0.00321) & (0.00302) & (0.0400) & (0.0389) & (0.0361) & (0.0344)\end{array}$

Demo.

Credits/gpa at first term

Initial earnings

$\mathrm{X}$

$\begin{array}{cc}\mathrm{X} & \mathrm{X} \\ \mathrm{X} & \mathrm{X} \\ \mathrm{X} & \mathrm{X} \\ & \mathrm{X} \\ & \mathrm{X}\end{array}$

$\mathrm{X}$

$\begin{array}{ll}\mathrm{X} & \mathrm{X} \\ \mathrm{X} & \mathrm{X} \\ \mathrm{X} & \mathrm{X} \\ & \mathrm{X} \\ & \mathrm{X}\end{array}$

Cohort

$318375 \quad 307331 \quad 279273 \quad 279273$

161560

156400

143664

143664

Control variables include age at entry, race, gender, hours attempted during the first term enrolled, GPA during first term enrolled, earnings during first term enrolled, as well as cohort/time/institution fixed effects. 
Appendix Table 3a: Effects on GPA and Financial Aids (design 1)

(1)

(4)

(5)

(6) (7)

Has Financial Aid

(8)

GPA

$\begin{array}{cccccccc}-0.00286 & 0.00207 & -0.00243 & -0.000964 & 0.00757 & 0.00735 & 0.00308 & -0.00306 \\ (0.0118) & (0.0120) & (0.0122) & (0.0122) & (0.00605) & (0.00616) & (0.00593) & (0.00574)\end{array}$

Demo.

Credits/gpa at first term

$\mathrm{X}$

$\begin{array}{ll}\mathrm{x} & \mathrm{x} \\ \mathrm{x} & \mathrm{x} \\ \mathrm{x} & \mathrm{x} \\ & \mathrm{x} \\ & \mathrm{x}\end{array}$

$\begin{array}{cc}\mathrm{x} & \mathrm{x} \\ \mathrm{x} & \mathrm{x} \\ \mathrm{x} & \mathrm{x} \\ & \mathrm{x} \\ & \mathrm{x}\end{array}$

Cohort

$\begin{array}{llll}125128 & 121167 & 113652 & 113652\end{array}$

69071

66661

62221

62221

Control variables include age at entry, race, gender, hours attempted during the first term enrolled, GPA during first term enrolled, earnings during first term enrolled, as well as cohort/time/institution fixed effects. 
Appendix Table 3b: Effects on GPA and Financial Aids (design 2)

(1)

(2)

(3)

(4)

(5)

(6) (7)

Has Financial Aid

(8)

GPA

$\begin{array}{lccccccccc}\text { Firm layoff in 1st year } & -0.00272 & -0.00426 & -0.00642 & -0.00640 & 0.0143^{* * *} & 0.0154^{* * *} & 0.0103^{*} & 0.00478 \\ & (0.0121) & (0.0122) & (0.0127) & (0.0127) & (0.00598) & (0.00609) & (0.00595) & (0.00575)\end{array}$

Demo.

Credits/gpa at first term

Initial earnings

Institution

Cohort
$\mathrm{X}$

$\begin{array}{ll}\mathrm{X} & \mathrm{X} \\ \mathrm{X} & \mathrm{X} \\ \mathrm{X} & \mathrm{X} \\ & \mathrm{X} \\ & \mathrm{X}\end{array}$

$\mathrm{X}$

$\begin{array}{ll}\mathrm{X} & \mathrm{X} \\ \mathrm{X} & \mathrm{X} \\ \mathrm{X} & \mathrm{X} \\ & \mathrm{X} \\ & \mathrm{X}\end{array}$

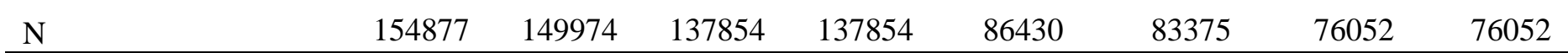

Control variables include age at entry, race, gender, hours attempted during the first term enrolled, GPA during first term enrolled, earnings during first term enrolled, as well as cohort/time/institution fixed effects. 